\title{
Vegetation cover and land use of a protected coastal area and its surroundings, southeast Brazil
}

Cobertura vegetal e uso da terra de uma área costeira protegida e seu entorno no sudeste do Brasil

\author{
Elisa Araujo Penna Caris ${ }^{1,6}$, Bruno Coutinho Kurtz ${ }^{2}$, \\ Carla Bernadete Madureira Cruz ${ }^{1,3}$ \& Fabio Rubio Scarano ${ }^{4,5}$
}

\begin{abstract}
We applied remote sensing techniques on a TM Landsat 5 image (1:50,000) to map land use and vegetation cover of the Restinga de Jurubatiba National Park and surroundings. The thematic map generated from the digital classification of the image allowed us to spatially characterize and quantify the different land uses and soil covers of the area. Thirteen classes were identified. The most representative classes in the park were the Clusia (31.99\%) and Ericaceae formations (29.14\%). More than 90\% of the park is occupied by native vegetation and coastal lagoons. The surroundings are very much altered by human activities (e.g. 70.64\% is used for agriculture and/or cattle raising). Two hundred and three forest fragments ( 0.3 to 235 ha) were identified, of which $45.3 \%$ are less than 5 ha. Most fragments (56.7\%) have a very elongated shape, and are thus submitted to an intense edge effect. The intense fragmentation of the surroundings and the isolation of this protected area can imply, in the long run, the loss of genetic diversity.
\end{abstract}

Key words: Atlantic forest complex, landscape ecology, protected areas, remote sensing, restinga.

\section{Resumo}

Foram aplicadas técnicas de sensoriamento remoto em uma imagem TM Landsat 5 (1:50.000) para mapear uso e cobertura vegetal do Parque Nacional da Restinga de Jurubatiba e seu entorno. O mapa temático gerado a partir da classificação digital da imagem permitiu caracterizar espacialmente e quantificar os diferentes usos e coberturas do solo da área. Treze classes foram identificadas. As classes mais representativas no parque foram as formações de Clusia (31,99\%) e Ericaceae (29,14\%). Mais de 90\% do parque é ocupado por vegetação nativa e lagoas costeiras. O entorno está muito mais alterado por atividades humanas (e.g. 70,64\% são utilizados para agricultura e/ou pastagem). Duzentos e três fragmentos florestais (0,3 a 235 ha) foram identificados, dos quais $45,3 \%$ menores que 5 ha. A maioria dos fragmentos $(56,7 \%)$ tem a forma muito alongada, estando assim submetidos a um forte efeito de borda. A intensa fragmentação do entorno e o isolamento desta área protegida podem implicar, em longo prazo, em perda da diversidade genética.

Palavras-chave: Complexo da Floresta Atlântica, ecologia da paisagem, áreas protegidas, sensoriamento remoto, restinga.

\section{Introduction}

The concept of national parks, as it first appeared in nineteenth century United States, was based on romantic visions of the beauty of nature and wilderness preservation. This was soon redefined as the preservation of complex ecosystems and maintenance of biodiversity (Hironaka 2003) in different types of reserves collectively called protected areas - of which national parks are only one of them. Although the practice of creating protected areas fastly spread worldwide, these sites often present problems

\footnotetext{
${ }^{1}$ Laboratório de Sensoriamento Remoto e Estudos Ambientais - ESPAÇO, Av. Brigadeiro Trompowski s/n, CCMN, bl. I - S/I-102, 21945-970, Rio de Janeiro, RJ, Brasil.

${ }^{2}$ Instituto de Pesquisas Jardim Botânico do Rio de Janeiro, Diretoria de Pesquisa Científica, R. Pacheco Leão 915, s/ 115, 22460-030, Rio de Janeiro, RJ, Brasil.

${ }^{3}$ Universidade Federal do Rio de Janeiro, Inst. Geociências, Depto. Geografia, Av. Brigadeiro Trompowski s/n, CCMN, bl. I-S/I-102, 21945-970, Rio de Janeiro, RJ, Brasil.

${ }^{4}$ Universidade Federal do Rio de Janeiro, CCS, Inst. Biologia, Depto. Ecologia, C.P. 68020, 21941-970, Rio de Janeiro, RJ, Brasil.

${ }^{5}$ Conservation International, R. Buenos Aires 68, $26^{\circ}$ an., 20070-022, Rio de Janeiro, RJ, Brasil.

${ }^{6}$ Corresponding author: elisacaris@yahoo.com.br
} 
such as isolation and poor connection to other wild areas (e.g. Ayres et al. 2005). Thus, the focus on wilderness islands has been gradually shifting towards a landscape mosaic view, where networks of different types of protected areas (Metzger 2006) are fostered. Ecological corridors, for instance, are now an obvious way to perform environmental protection across size scales (Fonseca et al. 2004; Hilty et al. 2006).

This upscale movement towards a landscape approach, when dealing with protected areas, often requires application of remote sensing techniques on satellite images (e.g. Richter et al. 2004). Selection of viable and priority habitats for conservation (Anacleto et al. 2005; Ayres et al. 2005) and analysis of land use patterns and changes in time (Martins et al. 2006) are common procedures to which such tools are applied.

In this study we applied remote sensing techniques to provide a descriptive account of vegetation cover and land use of a national park protecting a coastal sandy plain ecosystem in southeast Brazil, locally named restinga, and its surroundings, here defined as a $10 \mathrm{~km}$ wide buffer. Our interest in this vegetation type derives from the fact that literature indicates a strong biogeographic and ecological influence of the neighboring Atlantic rain forest (Scarano 2002, 2009). For instance, it has been reported that restinga vegetation is composed by at least $80 \%$ of plant species originated from such rain forest (Araujo 2000). This descriptive effort allowed us to address two issues that are relevant to the conservation of this national park: (1) what is the land-use pattern of the national park's surroundings? And (2) how this landscape-level analysis relates to the prevalent classification of local plant communities proposed by Araujo et al. (1998)?

\section{Material and Methods}

\section{Study Area}

The Restinga de Jurubatiba National Park $\left(22^{\circ} 08^{\prime}-22^{\circ} 19^{\prime} \mathrm{S} ; 41^{\circ} 17^{\prime}-41^{\circ} 43^{\prime} \mathrm{W}\right)$ is located in the north coast of the state of Rio de Janeiro, southeast Brazil (Fig. 1). It was created on April 29th, 1998, to protect an area of 14,838 ha of sandplains and coastal lagoons, representing one of the largest restinga ecosystems protected by federal law (Rocha et al. 2004). Jurubatiba appeared suitable for this type of study both because the results can contribute to its management and also for the fact that it has a long tradition of biodiversity research, since it houses a site of the Brazilian Long-Term Ecological Research Programs (Barbosa et al. 2004).
Unlike most sandy coastal plains in Rio de Janeiro, which date from the Holocene, the Jurubatiba plains consist of a series of parallel pleistocenic beach ridges (120,000 yr BP) formed by the silting of marine sediments (Martin et al. 1993). These beach ridges reach a maximum $10 \mathrm{~km}$ wide. The region is formed by three geomorphologic provinces: mountain region (area of occurrence of Precambrian crystal rocks), Tertiary tablelands (tabuleiros) and Quaternary sandy plains (see Martin et al. 1993). The park protects the Quaternary sandy plains, which display ten different plant communities according to Araujo et al. (1998): three forest formations, three open scrub areas, one closed scrub area, two grassland formations and one aquatic formation. The surroundings are composed mainly of Tertiary ground. Climate is Köppen's Aw tropical rainy type, with hot and rainy summer and dry winter (Henriques et al. 1986).

\section{Image processing}

A Landsat 5 TM image (July 4th, 2005, referenced for the path/row 216/75) was used to generate the image map and the thematic map.

Geometric image correction was made using the Spring Software (version 4.1), based on an image of the same scene existent at the Laboratory of Remote Sensing and Environmental Studies ESPAÇO (Institute of Geosciences, Federal University of Rio de Janeiro). Control points distributed through the image, in places of easy recognition as highways, river mouths etc., were chosen. The root mean square error of the test points was of $56.04 \mathrm{~m}$ that is in accordance with the specification for cartographic accuracy standard for the scale proposed in category C (Cruz \& Barros 2012), for elaboration of the image and thematic map. The projection used was UTM and datum WGS 84.

The limits of the national park were obtained in "shape" format (www.ibama.gov.br) with the North American 1927 datum. Datum transformation and the surrounding buffer (Fig. 1) were made in ArcMap module from ArcGis software (version 9.1).

We used a classification based on object (GEOBIA) (Cruz et al. 2007) developed in the software e-Cognition 4.0. The definition of the classes and the choice of the samples that would represent each one of these classes were based on the description of the plant communities at the national park (Araujo et al. 1998), and on the data acquired in field works performed during the years of 


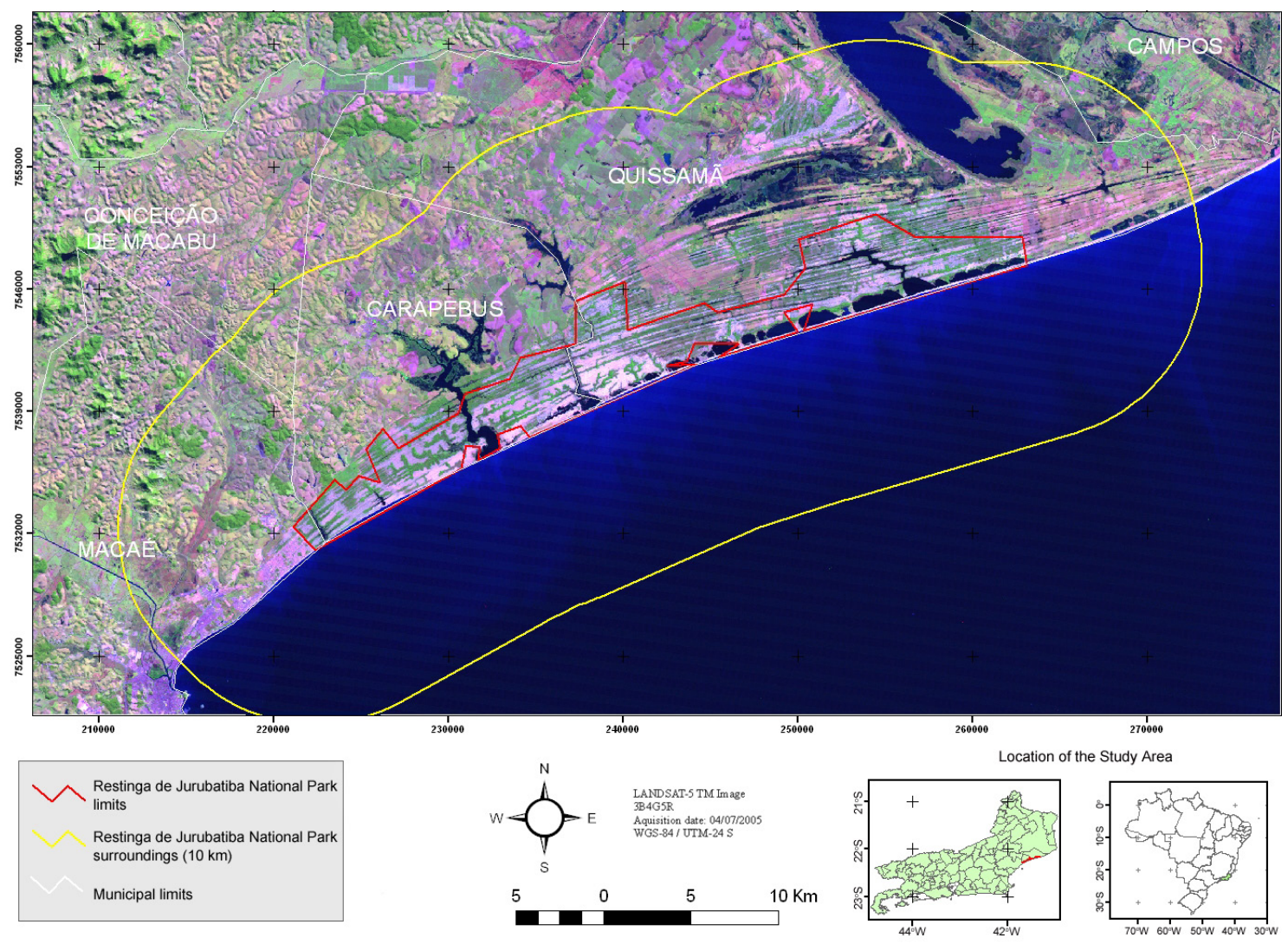

Figure 1 - Landsat 5 TM image showing the Restinga de Jurubatiba National Park and surroundings.

2005 and 2007. In this occasion, the area of the national park and of the surroundings were surveyed by car in almost their entire extensions and GPS landmarks were annotated as sample areas for classification and to minimize uncertainty in the final editing process.

The scale parameter used for segmentation was 10 and the bands used were 1 (blue); 2 (green); 3 (red); 4 (near-infrared); 5 (mid-infrared) and 7 (mid-infrared). A first classification was generated based on the nearest neighbor, and a second one was generated based on modeling the descriptors average, standard deviation and ratio between all bands, and NDVI (normalized difference vegetation index). The GEOBIA classification allows for the association of a wide range of descriptors during the analysis of the best set of rules that would permit a more accurate class discrimination. In this case, this mean NDVI associated to reflectance values of some isolated bands allowed the discrimination of some classes.

The process adopted for classification is not totally automatized. Even with the supervision of a specialist to establish the rules, there is a need to perform final manual editions. This procedure used the image 5R4G3B and the software ArcGis (9.1).

To calculate the overall accuracy of the mapping, we used the tool "create random points", in ArcGIS software version 9.3. It was decided to generate to each class 10 random points, since one of the classes is nearly $50 \%$ of the mapping. These points were projected on images (2005) available on Google Earth. Then, it was generated a confusion matrix, whose diagonal represents the overall accuracy. Later, the classes were quantified for the park and its surroundings.

A circularity index (CI) was obtained for each forest fragment presented in the surroundings, following the equation $C I=(2 \sqrt{\pi S}) / P$, where $S=$ area and $\mathrm{P}=$ perimeter of the fragment (Nascimento et al. 2006). According to Viana \& Pinheiro (1998), CI < 0.6 indicates that the fragments are "too elongated", between 0.6 and 0.8 , "elongated", and $>0.8$, "rounded" very elongated and elongated fragments are supposedly more subjected to border effects. 


\section{Results and Discussion}

The legend of Figure 2 is the result of the automatic classification process combined with visual image interpretation and includes 13 classes of land use and soil cover for the national park and its surroundings. The overall accuracy of the mapping was $95 \%$. The areas and percentages of each class are presented in Table 1. Due to the spatial resolution of $30 \mathrm{~m}$, classes of vegetation cover comprised, in certain cases, more than one plant community described by Araujo et al. (1998). A description of classes is presented in Table 2.

Differently from some studies using remote sensing techniques already developed in this site (Henriques et al. 1986; Oliveira-Galvão 1991; Cruz et al. 2003; Jamel 2004), we sought to correlate the classes for use and cover of the soil with the vegetation communities defined by Araujo et al. (1998), as well as to quantify these classes.

The most predominant class at the park was the Clusia formation (31.99\%), where density of vegetation islands varies, thus generating different spectral images. Oliveira-Galvão (1991) recognized a "light" Clusia formation (less thicket density and greater level of anthropization) and a "dark" Clusia formation, but our study included both in the Clusia formation. The open formation of Palmae was included in the Clusia class. Second was the Ericaceae formation (29.14\%), best represented between the Paulista lagoon and the extreme northeast of the park, where the sandy ridges are narrower. This formation is composed by three physiognomies forming together strips parallel to the sea. Taken jointly, it is easy to distinguish the Ericaceae formation, but when there are wider ridges we can confuse them with the Clusia formation, because the spectral response is very similar. Therefore, the distinction between these formations is only possible through confirmation in the field, as done here. The mapping by Henriques et al. (1986), which covered the southwest portion of the park, established a representativeness of $41.2 \%$ for the Clusia formation and $9.1 \%$ for the Ericaceae formation. These figures, especially for

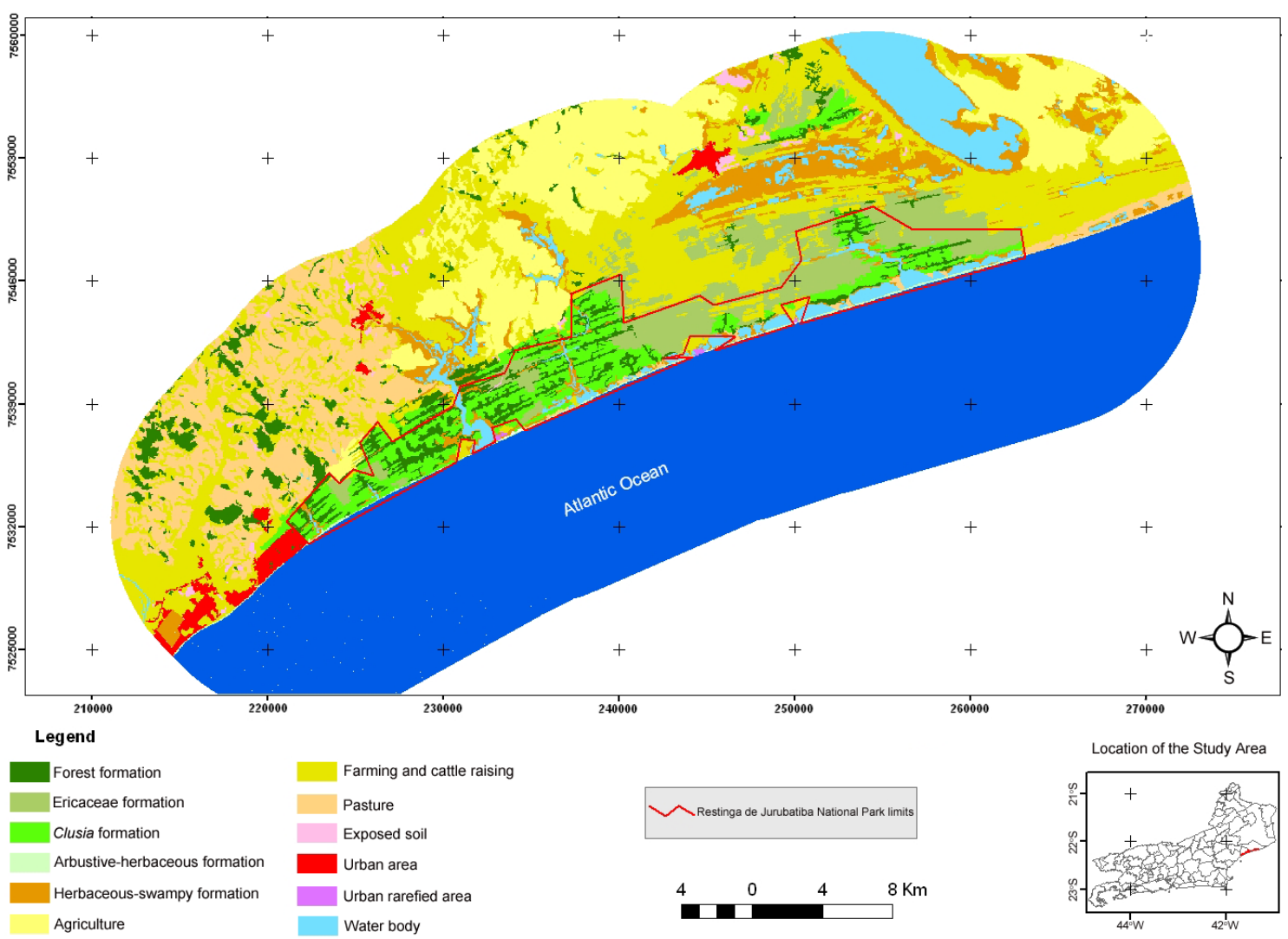

Figure 2 - Map of vegetation cover and land use at the Restinga de Jurubatiba National Park and surroundings. 
Table 1 - Area and percentage of classes of land use and vegetation cover of the Restinga de Jurubatiba National Park and surroundings.

\begin{tabular}{|c|c|c|c|c|}
\hline \multirow[t]{2}{*}{ Classes } & \multicolumn{2}{|c|}{$\begin{array}{l}\text { National } \\
\text { Park }\end{array}$} & \multicolumn{2}{|c|}{$\begin{array}{l}\text { Surroundings } \\
(10 \mathrm{~km})\end{array}$} \\
\hline & $\begin{array}{l}\text { Area } \\
\text { (ha) }\end{array}$ & $\%$ & $\begin{array}{l}\text { Area } \\
\text { (ha) }\end{array}$ & $\% *$ \\
\hline Forest formation & 2343.03 & 15.73 & 3204.82 & 4.41 \\
\hline Clusia formation & 4766.05 & 31.99 & 1094.28 & 1.51 \\
\hline Ericaceae formation & 4341.68 & 29.14 & 3437.27 & 4.73 \\
\hline $\begin{array}{l}\text { Herbaceous-swampy } \\
\text { formation }\end{array}$ & 768.64 & 5.16 & 6439.42 & 8.87 \\
\hline $\begin{array}{l}\text { Shrubby-herbaceous } \\
\text { formation }\end{array}$ & 325.02 & 2.18 & 103.67 & 0.14 \\
\hline Agriculture & 10.45 & 0.07 & 13924.26 & 19.17 \\
\hline Pasture & 146.74 & 0.98 & 10997.76 & 15.14 \\
\hline $\begin{array}{l}\text { Farming and cattle } \\
\text { raising }\end{array}$ & 571.83 & 3.84 & 26389.85 & 36.33 \\
\hline Exposed soil & 7.74 & 0.05 & 589.83 & 0.81 \\
\hline Urban area & 0 & 0 & 1470.24 & 2.02 \\
\hline Urban rarefied area & 0.78 & 0.01 & 39.91 & 0.05 \\
\hline Water body & 1344.87 & 9.03 & 4944.79 & 6.81 \\
\hline Atlantic Ocean & 270.38 & 1.81 & 57921.49 & - \\
\hline Total & 14897.21 & 100 & 72662.83 & 100 \\
\hline
\end{tabular}

the Ericaceae formation, are very different from our study and show the non-uniform distribution of these formations along the site.

The herbaceous-swampy formation covers $5.16 \%$ and includes aquatic vegetation. It often forms extensive areas in the shallowest zones of the lagoons near their margins, and frequently borders the permanently and periodically flooded woods. The shrubby-herbaceous formation $(2.18 \%)$ comprises two vegetation communities: the reptant halophila-psammophila and the post-beach dense shrubby form. In many parts of the park, this formation was totally or partially degraded due to the construction of an oil pipeline (recently removed) and placement of coarse clayey-sand for vehicle transit, in addition to transit of 'off-road' vehicles (pers. obs.). Finally, forest formation contributes with $15.73 \%$ of the area, encompassing three physiognomies. These results highlight one of the main peculiarities of restinga vegetation in this part of the coast: although plants mostly originate from the Atlantic rain forest, the predominant local formations are open vegetation, often with rain forest tree species that assume shrubby habit (see Scarano 2009).
The water bodies represent $9.03 \%$ of the national park area. This includes all 18 coastal lagoons. These lagoons are shallow, with depths not over $3 \mathrm{~m}$, and show considerable salinity variations among them (Enrich-Prast et al. 2004). The Atlantic Ocean was included as a class to be quantified, for being part of the official limits of the national park and it represents $1.81 \%$ of its area.

Over $90 \%$ of the park comprises native vegetation formations and water bodies. However, it would be desirable that degraded areas and/ or areas transformed into pasture and used for agriculture $(4.89 \%)$ were recovered, which requires land tenure regularization. In this sense, the recent successes in ecological restoration of sandy coastal plains (e.g. Zamith \& Scarano 2006) are encouraging.

Since a great part of the hydrological system of the region (lagoons, rivers and areas subject to floods; Martin et al. 1993) drains into the park, any impact or contamination (including the water table) by domestic sewage, chemical defensives and fertilizers can compromise its integrity (see Soffiati 1998).

The surroundings of the park encompass the municipalities of Macaé, Carapebus, Quissamã, Conceição de Macabu and Campos dos Goytacazes. The Atlantic Ocean responds for $44 \%$ of the surrounding area of the park, followed by cattle raising farms $(36.33 \%)$, agriculture $(19.17 \%)$ and pastures $(15.14 \%)$. Those three terrestrial classes together add up to $70.64 \%$ of the land use. Agriculture is represented mainly by sugar cane, although other cultures (e.g. coconut) are also found. In many cases, there are areas used both for agriculture and pasture. In the northern limit of the national park, the pasture areas reach the coastline. The agricultural activities removed the vegetation cover and changed the landscape, often entailing negative impacts in the study site. Typical examples are sugar-cane farming and the risks of associated fires, as well as the extensive grazing of cattle (that is already moving towards the interior of the national park). The lack of settlement of the land situation hinders the effective supervision of the protected area and its surroundings. Furthermore, it is apparent that most properties do not abide to the Brazilian forest code legislation (see Lewinsohn 2010; Metzger 2010). The result is that the forest fragments $(\mathrm{N}=203 ; 4.41 \%$ of the area) remaining in the surroundings of the park are usually isolated by a matrix composed of agriculture and cattle 


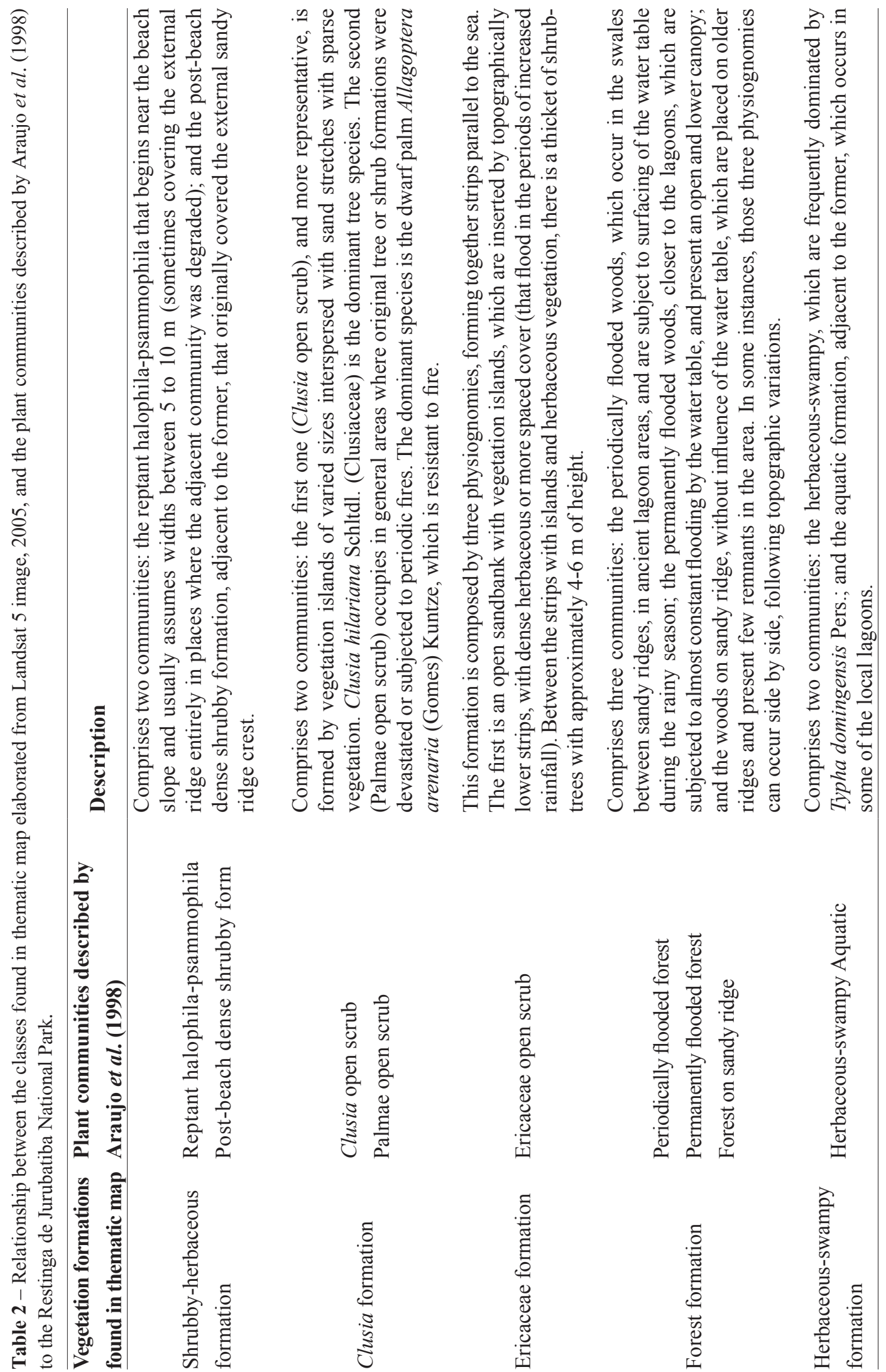


raising activities. This adds to the difficulty for preservation of those fragments and puts their sustainability at risk (see Viana \& Pinheiro 1998). The smallest fragment is 0.3 ha while the largest is $235 \mathrm{ha}$. The latter is located on a slope, which may have favored its preservation. Fragments < 5 ha are the most frequent (45.3\%), which is a common pattern elsewhere in the Atlantic forest domain (e.g. Ribeiro et al. 2009). These studies highlight the biological relevance of preserving such small fragments.

More than half $(56.7 \%)$ of the forest fragments presented a "very elongated" shape (Tab. 3) and would, therefore, be subject to greater border effect (Viana \& Pinheiro 1998). Considering that restinga species were mostly originated in the Atlantic forest, preservation and restoration of fragments in the surroundings of the national park should be essential to maintain gene flow and local biodiversity. Moreover, there are no available floristic surveys of such fragments.

Additional classes in the national park surroundings include water bodies $(6.81 \%)$; herbaceous-swampy (8.87\%); remnants of Clusia $(1.51 \%)$ and Ericaceae $(4.73 \%)$ formations inside private properties and used for pasture; small remnants of the shrubby-herbaceous formation $(0.14 \%)$ along the coastline, not yet destroyed by the construction of houses, pasture or transit of vehicles; and urban areas (2.02\%) that do not have intense vertical constructions or large populations, except for an initially illegal housing development that borders the southwest limit of the park. Finally, beach houses at Carapebus (municipality of Carapebus), João Francisco and Visgueiro (municipality of Quissamã) correspond to the urban rarefied area $(0.05 \%)$ and its impact on the national park is felt especially during weekends, holidays and vacation periods. The bare soil class $(0.81 \%)$ is found along the entire park surrounding, without specific concentration.

Our study showed that the surroundings of this protected area are highly fragmented (see also Cruz et al. 2003). This results in a virtual isolation of the national park from the regional remnants of Atlantic Forest, which are located mainly on slopes of the Serra do Mar in a range that here varies from 10 to $30 \mathrm{~km}$ on a straight line. In this scenario, the reduction of gene flow may be critical to maintaining the diversity and functioning of the local restinga. Furthermore, resilience to climate change also diminishes (Scarano \& Garbin 2013).
Table 3 - Form of forest fragments in the surroundings of the Restinga de Jurubatiba National Park, calculated by the circularity index.

\begin{tabular}{ccc}
\hline Form of fragments & Number of fragments & $\%$ \\
\hline Circular & 18 & 8.9 \\
Elongated & 70 & 34.5 \\
Very elongated & 115 & 56.7 \\
\hline
\end{tabular}

Restoration efforts, especially aimed at the creation of corridors, should also target the continent-sea axis, rather than focusing only the continentcontinent axis.

The thematic map produced based on the digital classification of the Landsat 5 image allowed for a spatial characterization of the different uses and soil cover of the national park and its surroundings. The difficulty in determining all plant communities described for the park by Araujo et al. (1998) led to a simplification of the legend. This was due to the spatial resolution of $30 \mathrm{~m}$ of the sensor. Since the limits between plant formations is very thin, the use of high resolution images would have favored a better class discrimination, as shown elsewhere (Kurihara \& Encinas 2003; Dlugosz et al 2005; Caris et al 2009). However, given the high costs of acquisition of such images and the time needed to digitally process the data, images of medium resolution, as the one used in this study, offer a better cost-benefit ratio. For this reason these images and their products have been frequently used as important tools in the management of protected areas (e.g. Richter et al. 2004).

\section{Acknowledgements}

We thank the Brazilian Environmental Agency (IBAMA) for working permits and local staff for logistic support; J. Caruzo, O. Faber, T.S. Conceição and Keidel, G. for field and technical assistance; the Research Center of the Brazilian Oil Company (Cenpes-Petrobras) for financial support; the National Institute for Space Research (INPE) for the Landsat image cession; R.R. Oliveira, L.M.M. Liu, D.S.D. Araujo, C.A. Bohrer and anonymous reviewers for critical reading of the manuscript; and Brazilian Research Council (CNPq) for productivity grant to FRS.

\section{References}

Anacleto, T.C.S.; Ferreira, A.A.; Diniz Filho, J.A.F. \& Ferreira, L.G. 2005. Seleção de áreas de interesse 
ecológico através de sensoriamento remoto e de otimização matemática: um estudo de caso no município de Cocalinho, MT. Acta Amazônica 35: 437-444.

Araujo, D.S.D.; Scarano, F.R.; Sá, C.F.C.; Kurtz, B.C.; Zaluar, H.L.T.; Montezuma, R.C.M. \& Oliveira, R.C. 1998. Comunidades vegetais do Parque Nacional da Restinga de Jurubatiba. In: Esteves, F.A (ed.). Ecologia das lagoas costeiras do Parque Nacional da Restinga de Jurubatiba e do município de Macaé. NUPEM-UFRJ, Rio de Janeiro. Pp. 37-62.

Araujo, D.S.D. 2000. Análise florística e fitogeográfica das "restingas" do estado do Rio de Janeiro. Tese de Doutorado. Universidade Federal do Rio de Janeiro, Rio de Janeiro. 176p.

Ayres, M.; Fonseca, A.B.G.; Rylands, A.B.; Queiroz, H.L.; Pinto, L.P.S.; Masterson, D. \& Cavalcanti, R.B. 2005. Os corredores ecológicos das florestas tropicais do Brasil. Sociedade Civil Mamirauá, Belém. 256p.

Barbosa, F.A.R.; Scarano, F.R.; Sabara, MG. \& Esteves, F.A. 2004. Brazilian LTER: ecosystem and biodiversity informations in support of decisionmaking. Environmental Monitoring and Assessment 90: 121-133.

Caris, E.A.P.; Kurtz, B.C.; Cruz, C.B.M. \& Scarano, F.R. 2009. As perspectivas do uso de imagens de alta resolução em estudos ecológicos - um estudo de caso para o Parque Nacional da Restinga de Jurubatiba, RJ. In: Anais XIV Simpósio Brasileiro de Sensoriamento Remoto. Instituto de Pesquisas Espaciais, Natal. Pp:2637-2644.

Cruz, C.B.M.; Freitas, S.R.; Seabra, V.S.; Barros, R.S. \& Medeiros, A.F.F. 2003. Dinamismo Ambiental do Parque Nacional de Jurubatiba e seu entorno - Rio de Janeiro. In: Anais XXI Congresso Brasileiro de Cartografia. Sociedade Brasileira de Cartografia, Belo Horizonte.

Cruz, C.B.M.; Vicens, R.S.; Seabra, V.S.; Reis, R.B.; Faber, O.A.; Arnaut, P.K.E \& Araujo, M. 2007. Classificação orientada a objetos no mapeamento dos remanescentes da cobertura vegetal do bioma Mata Atlântica, na escala 1:250.000. In: XIII Simpósio Brasileiro de Sensoriamento Remoto. Instituto de Pesquisas Espaciais, Florianópolis. Pp. 5961-5698

Cruz, C.B.M. \& Barros, R.S. 2012. Contribution of new sensors to cartography. In: C. Bateira, Cartography - A Toll for Spatial Analysis. InTech, DOI. Disponível em $<$ http://www.intechopen.com/ books/cartography-a-tool-for-spatial-analysis/ contribution-of-new-sensors-to-cartography>. Acesso em 15 Abr 2013.

Dlugosz, F.L.; Rosot, N.C.; Rosot, M.A.D. \& Oliveira, Y.M.M. 2005. Uso da segmentação por crescimento de regiões em imagens Ikonos na discriminação de tipologias da Floresta Ombrófila Mista. In: Anais do XII Simpósio Brasileiro de Sensoriamento
Remoto. Instituto de Pesquisas Espaciais, Goiânia. Pp. 1493-1500.

Enrich-Prast, A.; Bozelli, R.L.; Esteves, F.A. \& Meirelles, F.P. 2004. Lagoas costeiras da restinga de Jurubatiba. In: Rocha, C.F.D.; Esteves, F.A. \& Scarano, F.R (eds.). Pesquisas de longa duração na Restinga de Jurubatiba: ecologia, história natural e conservação. Ed. RiMa, São Carlos. Pp. 245-253.

Fonseca, G.A.B.; Alger, K.; Pinto, M.; Araujo \& Cavalcanti, R. 2004. Corredores de biodiversidade: o corredor central da Mata Atlântica. In: Aruda, M.B. \& Sá, L.F.S.N (eds.) Corredores ecológicos: uma abordagem integradora de ecossistemas no Brasil. Ibama, Brasília. Pp. 47-65.

Henriques, R.P.B.; Araujo, D.S.D. \& Hay, J.D. 1986. Descrição e classificação dos tipos de vegetação da restinga de Carapebus, Rio de Janeiro. Revista Brasileira de Botânica 9: 173-189.

Hilty, J.A.; Lidicker, Jr. W.Z. \& Merenlender, A.M. 2006. Corridor ecology: the science and practice of linking landsacapes for biodiversity conservation. Island Press, Washington. 344p.

Hironaka, A. 2003. Science and the environment. In: Drori, G.S.; Meyer, J.W.; Ramirez, F.O. \& Schofer, E. (eds.). Science in the modern world polity. Stanford University Press, Stanford. Pp. 249-264.

Jamel, C.E.G. 2004. Caracterização da vegetação da Restinga de Jurubatiba com base em Sensoriamento Remoto e Sistema de Informações Geográficas: estado atual e perspectivas. In: Rocha, C.F.D.; Esteves, F.A. \& Scarano, F.R. (eds.). Pesquisas de longa duração na Restinga de Jurubatiba: ecologia, história natural e conservação. Ed. RiMa, São Carlos. Pp.25-42.

Kurihara, D.L. \& Encinas, J.I. 2003. Análise da arborização do Campus da Universidade de Brasília através de imagens Ikonos. Brasil Florestal 78:81-87.

Lewinsohn, T.M. 2010. The ABECO and the Brazilian Forest Code. Natureza \& Conservação 8: 100-101.

Martin, L.; Suguio, K. \& Flexor, J.M. 1993. As flutuações de nível do mar durante o quaternário superior e a evolução geológica de "deltas" brasileiros. Boletim do Instituto de Geologia - USP 15: 1-186.

Martins e Souza Filho, P.W.; Paradella, W.R. \& Souza Junior, C. 2006. Sensoriamento remoto e recursos naturais da Amazônia. Ciência e Cultura 58: 37-41.

Metzger, J.P. 2006. Novas perspectivas de conservação baseadas na Rcologia de Paisagens. In: Mariath, J.E.A.\& Santo, R.P. (eds.). Os avanços da botânica no início do século XXI - morfologia, fisiologia, taxonomia, ecologia e genética. Sociedade Botânica do Brasil, Porto Alegre. Pp. 453-456.

Metzger J.P. 2010. O Código Florestal tem base científica? Natureza \& Conservação 8:92-99.

Nascimento, M.C.; Soares, V.P.; Ribeiro, C.A.A.S. \& Silva, E. 2006. Mapeamento dos fragmentos de 
vegetação florestal nativa da bacia hidrográfica do Rio Alegre, Espírito Santo, a partir de imagens do satélite Ikonos II. Revista Árvore 30: 389-398.

Oliveira-Galvão, A.L.C. 1991. Caracterização fitofisionômica da Restinga de Carapebus, Macaé (RJ), a partir de imagens digitais do sensor TM - Landsat 5. Dissertação de Mestrado, Instituto Nacional de Pesquisas Espaciais, São José dos Campos. 223p.

Ribeiro, M.C.; Metzger, J.P.; Martensen, A.C.; Ponzoni, F.J. \& Hirota, M.M. 2009. Brazilian Atlantic forest: how much is left and how is the remaining forest distributed? Implications for conservation. Biological Conservation 142: 1141-1153.

Richter, M.; Cruz, C.B.M. \& Valentim, L. 2004. Análise do uso e ocupação do solo no Parque Nacional do Itatiaia a partir de produtos de Sensoriamento Remoto. In: Anais do IV Congresso Brasileiro de Unidades de Conservação, Vol. I, Trabalhos Técnicos. Rede Nacional Pró-Unidades de Conservação / Fundação O Boticário de Proteção à Natureza, Curitiba. Pp. 481-490.

Rocha, C.F.D.; Bergallo, H.G.; Alves, M.A.S. \& Sluys, M.V. 2004. A restinga de Jurubatiba e a conservação dos ambientes de restinga do estado do Rio de Janeiro. In: Rocha, C.F.D.; Esteves, F.A.
\& Scarano, F.R. (eds.). Pesquisas de longa duração na Restinga de Jurubatiba: ecologia, história natural e conservação. RiMa, São Carlos. Pp. 341-352.

Scarano, F.R. 2002. Structure, function and floristic relationships of plant communities in stressful habitats marginal to the Brazilian Atlantic rainforest. Annals of Botany 90: 517-524.

Scarano, F.R. 2009. Plant communities at the periphery of the Atlantic rain forest: rare-species bias and its risks for conservation. Biological Conservation 142: 1201-1208.

Scarano, F.R. \& Garbin, M.L. 2013. Stem species: the regenerating cells of Gaia. Nova Acta Leopoldina 114 (in press).

Soffiati, A. 1998. Aspectos históricos das lagoas do norte do estado do Rio de Janeiro. In: Esteves, F.A. (ed.). Ecologia das lagoas costeiras do Parque Nacional da Restinga de Jurubatiba e do Município de Macaé (RJ). NUPEM, UFRJ, Rio de Janeiro. Pp. 1-35

Viana, V.M. \& Pinheiro, L.A.F.V. 1998. Conservação da biodiversidade em fragmentos florestais. Série Técnica IPEF 12: 25-42.

Zamith, L.R. \& Scarano, F.R. 2006. Restoration of a restinga sandy coastal plain in Brazil: survival and growth of planted woody species. Restoration Ecology 14: 87-94. 